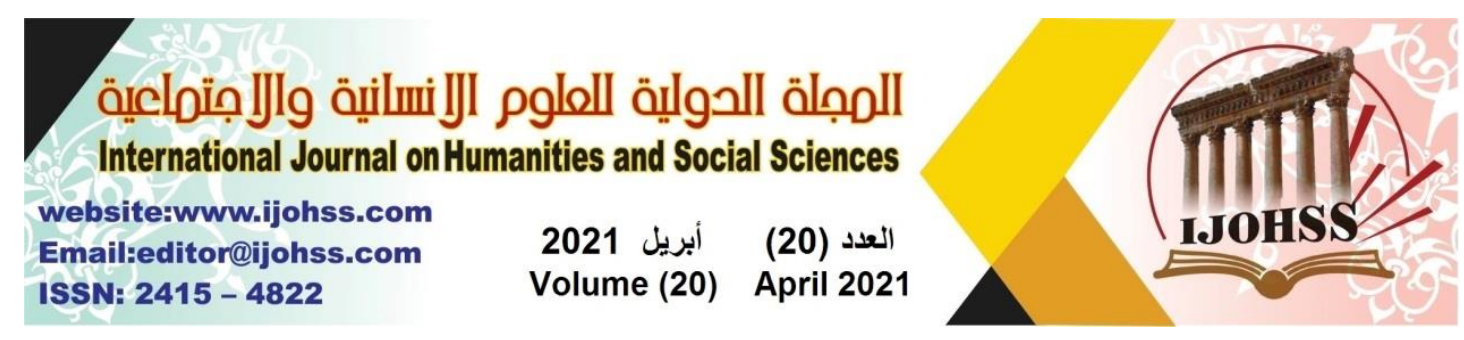

\title{
China-Pakistan Relations for the Next Decade (2020-2030)
}

\author{
Assistant Professor \\ Majeed Kamil Hamzah \\ University of Baghdad - Iraq \\ Email:majeed.kamel@cofarts.uobaghdad.edu.iq \\ https://orcid.org/0000-0002-5603-4096
}

\begin{abstract}
"China-Pakistan" relations are unique in their trends among all countries that neighboring China, as relations have developed from the level of political and military relations to a complete set of contacts and comprehensive relations, and these relations may only disturb some of the concerns from the Chinese side regarding the Islamic identity of Pakistan, especially with the emergence of the phenomenon of terrorism and extremist groups In Pakistan, the presence of the Islamic Igor minority in Xinjiang. China, as one of the major powers in the world, has considered development in various fields to be the focus of increasing international attention in recent years, as it may threaten the economic and military position of the United States in the future. Therefore, the strategic relationship between China and Pakistan should be understood from an international strategic perspective, specifically in the interrelated relations between China, the United States, India and Russia. The importance of the issue is highlighted in several aspects, the first of which is: China seeks to prevent American and Russian influence from leaking into the neighboring countries of China. Second: To break the isolation attempts that might strike the Chinese economy. Third: Striving to dominate the markets of the Middle East countries, especially the Arab countries and North and West Africa. Fourth, strengthening the Pakistan-China alliance in the face of the US-Indian alliance. Fifth: The "CPEC" project agreement, which would change the balance of international powers in the region. Sixth: Reviving the Pakistani economy by China construct the Pakistani "Gawadar Port" project, which will bring to Pakistan billions of dollars to provide transit facilities for the second largest economy in the world, and develops multiple economic sectors and creates countless job opportunities, providing a productive environment and eliminating destitute societies, which constitute Natural incubators for extremist thought and a productive environment for terrorism, within the framework of a comprehensive future economic vision for the year 2030 .
\end{abstract}

Keywords: China-Pakistan, Political and Economic Relations, United States, Economic Corridor, Gwadar Port. 


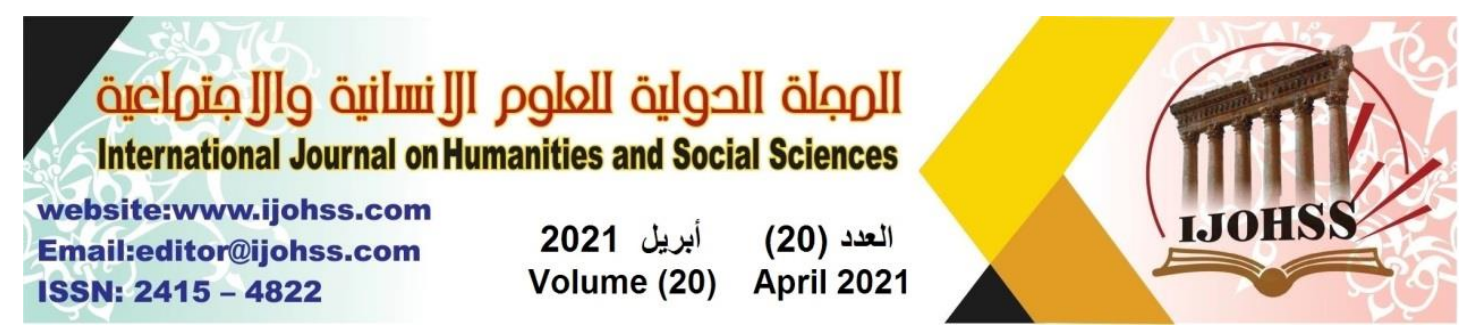

\section{INTRODUCTION:}

Introduction: With the end of the twentieth century and the beginning of the twentyfirst century, many political changes appeared on the international arena that resulted in new balances between the international powers as a result of the collapse of the Soviet Union, and the United States 'sole economic, political and military domination, and China emerged as an influential power in Asia, attracting a lot of eyes around it And it has made a lot of tremendous progress in many areas. It guaranteed regional and international supremacy. China is destined to have a permanent seat in the United Nations and the Security Council. The "China-Pakistan" relations are based on friendship and cooperation in the cultural, economic and commercial fields, despite the sharp ideological difference between the two political systems in both countries, as China adopts the codified communist ideology, while Pakistan is an Islamic country, yet it has preserved a set of interests and goals. The common denominator that brought them together throughout the duration of their relationship, which began with the decade of the fifties of the twentieth century with the emergence of the State of Pakistan in the Indian subcontinent in 1947, after its division into two states, India and Pakistan.

Significance: The importance of the issue of "China-Pakistan" relations in the next decade for both countries lies in the focus of the Chinese policy on preventing the penetration of American and Russian influence and the domination of their capabilities. China considered the Middle East and Africa as the link between Europe and the countries of Southeast Asia through land, air and sea crossings, especially the Red Sea, from the Suez Canal crossing to the Indian Ocean in the south. Accordingly, we find that China focused its relations on Middle Eastern countries such as Saudi Arabia, Egypt and Iran in general, and Pakistan in particular, and China began to penetrate the countries of the Middle East. Therefore, China had to think about the future of its existence as a giant economic power on the map of power balances in the world, by securing its global trade routes. "China-Pakistan" rapprochement allows the formation of a parallel alliance to the alliance between the United States and India, Pakistan's traditional enemy.

Hypothesis: The success of China and Pakistan in completing the "Joint Economic Corridor Project" "CPEC" and the Pakistani "Gwadar Port" project would change the balance of international powers in the region, and make the attempts to isolate and surround the Chinese economy less effective. At the same time, it contributes to reviving the Pakistani economy. It contributes to drawing the features of new economic powers that have more impact on the international scene in the next decade in 2030 . 


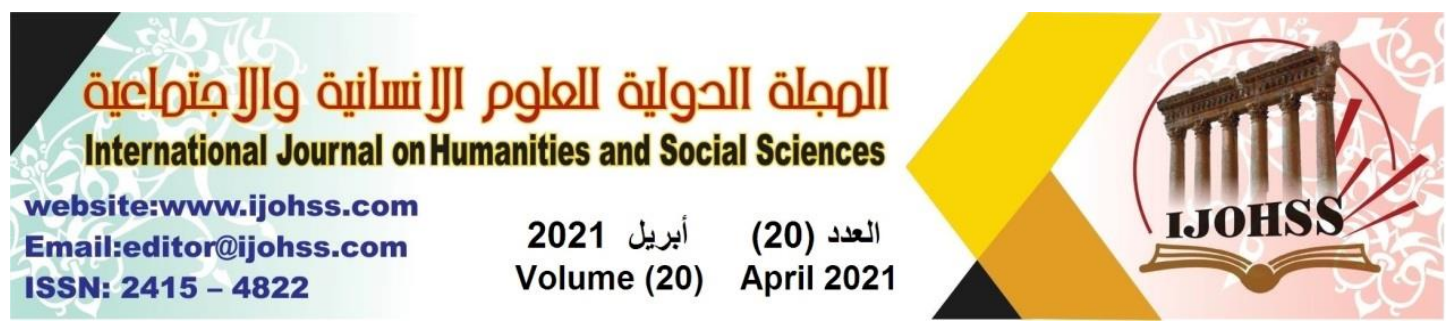

The First Topic \The Impact of "Chinese-Pakistani Relations" I- The Historical Impact (1950-2020):-

First Stage:- Diplomatic representation between China and Pakistan began in the year 1950, when Pakistan recognized the People's Republic of China. The two countries soon established formal diplomatic relations in 1951, making Pakistan the first among Islamic countries and the second in South Asia after India, which established diplomatic relations with Beijing. The two countries maintained normal bilateral relations throughout this period despite the ideological difference between the two regimes. However, after the United States proposed the "Baghdad Pact" in 1955, the (Santo Cento) Pact after Iraq left it in 1958, which was the alliance that was seeking to confront communism. In the region. Pakistan's accession to it and its entry into alliances with the United States in the context of confronting the Soviet Union in the Cold War, and also joining the "R.C.D Organization for Regional Development" ${ }^{[1]}$, As this organization had the most influential role in the rise of the Pakistani economy, Pakistan became an official member of the Western alliance. In addition to Pakistan signing a number of bilateral security agreements with the United States, on the other hand, the leaderships and the ruling elite in Pakistan tended to encourage Islamic values inside Pakistan, which encouraged Muslim minorities in China in turn to look forward to exercising their religious freedoms and rituals that are prohibited by the Chinese authorities, which is what China considered it a violation of its internal security and stability. These factors were reflected in the relations between the two countries throughout the fifties of the twentieth century, as they were characterized by stagnation and mutual suspicion of the goals and aspirations of each of them towards the other. ${ }^{[2]}$

The Second Stage:-During the sixties and seventies of the twentieth century, the two countries tended to restore calm in the course of their relations by signing an agreement demarcating the border between them in 1963, and China's provision of political, military and economic support to Pakistan, especially after the Bangladesh crisis. The main motive behind this was that China began practicing economic and diplomatic reforms different from the policies of the "Great Cultural Revolution" and bypassing the "sheltered" stage of "Chinese leader Mao Zedong." During that period, China adopted a policy of economic and political openness to the outside world. In light of the tense relations between China and India due to the border conflicts between the two countries and Pakistan's traditional enemy, China has been in solidarity with the Pakistani demands regarding "Kashmir" for the right to selfdetermination. The US President "Nixon" administration encouraged Pakistan to improve its relations with China, considering that this relationship could be the

[1] Yeşilbursa, Behçet Kemal (22 July 2009)."The Formation of RCD: Regional Cooperation for Development". Middle Eastern Studies. 45 (4): 637-660.

[2] Qasim Muhammad Jaafar, The Fourth Nuclear War in the Indian Subcontinent, Al-Wasat Magazine, No. 173, London, 1995, p. 38. 


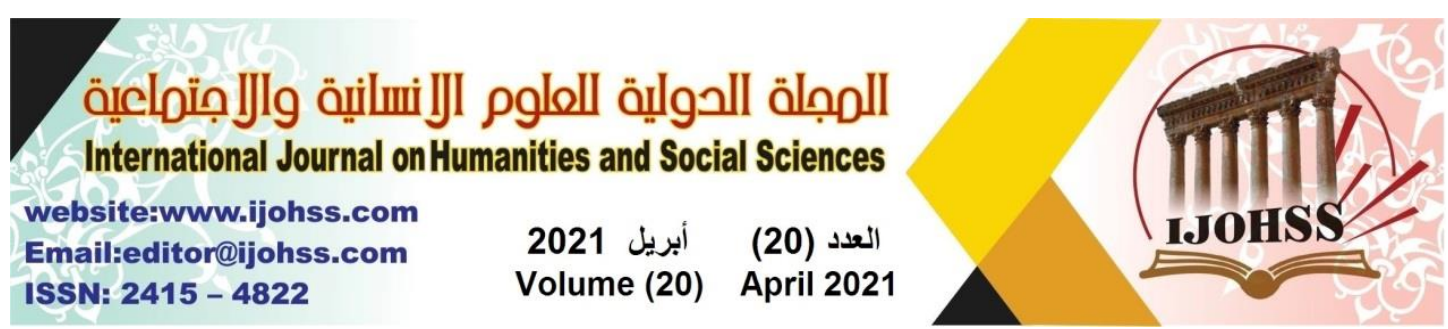

gateway for the United States to improve its relations with China, as well as trying to distance China from the alliance with the Soviet Union. ${ }^{[3]}$

These events encouraged the emergence of an informal alliance between China and Pakistan, which developed into a relationship and partnership that both countries benefited from at various diplomatic, economic and military levels. China, in return, provided economic aid and broad political support to Pakistan, and China continued to strengthen its relations with Pakistan, especially after and during the India-Pakistan war in 1971, which ended with the separation of East Pakistan and Bangladesh today. China announced its support for Pakistan in the Kashmir issue during the visit of Pakistani Prime Minister "Zulfikar Ali Bhutto" to Beijing in 1976. In turn, Pakistan also supported China in the issue of "Taiwan, Tibet, and Xinjiang" and other issues related to the core interests of China. ${ }^{[4]}$

The Third Stage:- With the start of the last two decades of the twentieth century, China provided economic and military aid to Pakistan, which suffered during the Soviet occupation of Afghanistan(1979-1988), and in 1986, China and Pakistan reached a comprehensive agreement for nuclear cooperation. After the collapse and disintegration of the Soviet Union in 1991, and the United States' dominance over the new world order, Chinese concerns about the American threats increased, so it tended to strengthen its strategic relations with India and Russia. Nevertheless, China maintained its relations with Pakistan in the fields of energy, oil, communications, agricultural development, attraction and settlement. ${ }^{[5]}$

The Fourth Stage:- The "China-Pakistan"relations witnessed another qualitative leap after the admission of Pakistan as an observer alongside Iran and India in the "Shanghai Cooperation Organization" in 2005, this helped to enhance regional cooperation in the field of security and stability in South Asia and the Indian Ocean region, which strengthened "China-Pakistan" relations The two countries signed the Treaty of Friendship, Cooperation and Good Neighborly Relations, in addition to (21) agreements in various fields between the two countries during the visit of Chinese Prime Minister Wen Jiabao to Pakistan in 2005, and in accordance with this treaty, the two countries pledge to assist each other in their efforts to protect the integrity and territorial integrity of their country. . In 2006, the two countries signed a free trade agreement to triple the volume of bilateral trade to 15 billion dollars. Under the agreement, the two countries began removing customs from all goods, starting from July 1, 2007. With Xi Jinping assuming power in Beijing in 2013, and China's proposal for a major strategy known as "One Belt and One Road", Pakistani-Chinese relations entered a new stage. From the strategic partnership that was crowned in

[3] Tariq Ali, Kissinger visit to China 1971, http://historypak.com,07 jun 2006.

[4]Associated Press of Pakistan, Pakistan and China relations: 65 years of friendship to strategic partnership,www.pakistantoday.com.pk,15 May 2016.

[5] Qahtani Mutlaq (2006). "The Shanghai Cooperation Organization and the Law of International Organizations" (PDF). Chinese Journal of International Law. Oxford University Press. 5 (1): 130. ISSN 1540. 


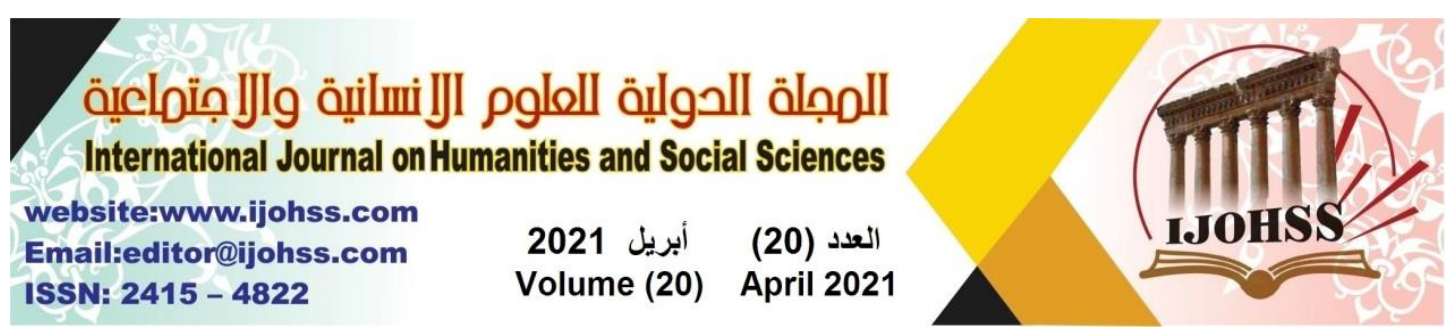

2015, with the launch of the "China-Pakistan Economic Corridor" project, during the Chinese President's visit to Islamabad. ${ }^{[6]}$

The Fifth Stage:- China and Pakistan focus on strengthening their relations in order to raise the level of bilateral relations, in an effort to reach more strategic communication in the relations between the two countries. China provides support to Pakistan's sovereignty on its soil and seeks to achieve development within Pakistan while preserving its external environment. Pakistan has several reasons pushing it to continue deepening its relations with China, including trying to mitigate the repercussions of the United States 'decision to suspend two billion dollars in military aid that it was providing to Pakistan, against the background of what Washington considers Pakistan's failure to do enough to confront terrorism, especially across the Afghan border. It is working on a regional reassessment of Pakistan's foreign and security policy. ${ }^{[7]}$

\section{II - Political Impact:-}

In 2007, Chinese President Jintao gave a speech in which he spoke about the necessity of rejuvenating the Chinese nation, and stressed the need for China to be able to use "soft power", to become a world emerging nation, instead of just rising regionally, and China not content itself with its military power Only, it must rely on its soft power in the face of the greater power, the United States. And the Chinese chose Pakistan as the starting point for the world after that. In accordance with the principle of "the enemy of my enemy is my friend", Beijing has strengthened and developed its relations with successive Pakistani governments. Chinese leaders found in the Indo-Pakistani hostility a golden opportunity to form an alliance with Pakistan that besieges India from the north and northwest. ${ }^{[8]}$

China and the United States understand that Pakistan hopes to have an impact on the regime in Afghanistan in the long term, and that Pakistan seeks to use its influence over the Taliban, Al Qaeda and other Islamic militants to achieve political, military and economic gains from the West. [14] From the Chinese point of view, Afghanistan and Pakistan are considered a geographic center between Central and South Asia, which represents a strategic location for the development of its "One Belt, One Road" project, as well as being the road to the Indian Ocean and the Arabian Sea away from

[6] Web Desk. Pakistan Receives LD-10 Anti-Radiation Missiles From China, http://pakchinanews.pk, 23 Aug 2006.

[7] John Garver (2016), "China and Iran: An Emerging Partnership Post-Sanctions, "Middle East Institue, $2016 \quad-02 \quad-08 . \quad$ http://www .mei.edu/content/china-and-iran-emergingpartnership-post-sanctions.

[8] Associated Press of Pakistan, Pakistan and China relations: 65 years of friendship to strategic partnership,www.pakistantoday.com.pk,15 May 2016. 


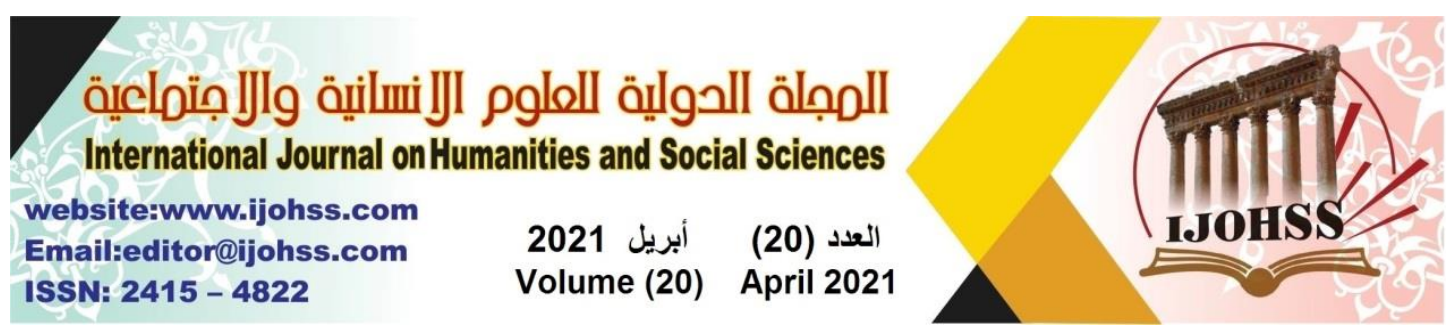

India. The Chinese government can also use its influence in Pakistan and Afghanistan to contain the spread of extremism in the Muslim region of "Xinjiang". [9]

There is a seriousness on the part of China in exploiting Pakistan's economic problems, its security conditions, and its desperate need for electric power to obtain direct access to the Indian Ocean and the Arabian Sea by constructing an economic corridor of three thousand kilometers, at a cost of $\$ 28$ billion, to connect the "Gwadar Port" located in Pakistani Balochistan is the city of Kashgar in the Chinese province of Xinjiang bordering Pakistan, which reduces the time of arrival of Gulf oil to China by thousands of kilometers. Beijing leaders believe that access to the waters of the Indian Ocean, in which India has a strong influence and overlooks all of its long coasts, is a goal that deserves large loans, aid and investment. ${ }^{[10]}$

\section{III- The Military and Security Impact:-}

1-Military and Defense Cooperation:- The cooperation between China andPakistan in the field of defense dates back to the early years of the establishment of Pakistan in 1947. China helped establish the Pakistan Aviation and Heavy Industries Complex in Taxila, and many production lines in Pakistani munitions factories, and projects Navy to naval and missile factories. ${ }^{[1]}$ As the Pakistan Aeronautics Complex in "Kamra", the heavy industries and the heavy mechanical complex, and the Pakistani steel plant in "Karachi". China has played the most important and prominent role in building and developing Pakistan's defense capabilities, especially during the eighties and nineties of the twentieth century. In 1992, Pakistan obtained a package of M-11 short-range ballistic missiles. China has also contributed to building and developing "F-7" warplanes and "K8" fighter jets, and within the framework of the joint defense production of weapons and equipment between Pakistan and China, the two countries have manufactured "Thunder JF 17" aircraft in the Pakistani Air Force complex. Aviation, which gave the Pakistani Air Force a qualitative edge at the level of the Air Force in the region ${ }^{[12]}$. China helped Pakistan develop unmanned aerial vehicles. As well as close cooperation in the field of maritime defense in the Indian Ocean and in the South China Sea. And to enhance maritime cooperation, navigation security, coast

[9] Chinese military base in the Pakistani port of Gawadar, New Gulf, January 8, 2018. https://thenewkhalij.news/index.php/article.

[10] Shen Yahsin (2015), "China-Pakistan Relations in Xin Jinping's Eye", People's Daily Online, 2015-04-17. http://politics.people.com.

[11]Yaroslav Trofimov (2015), “America's Fading Footprint in the Middle East," The Wall Street Journal, 2015-10-09. http://www.wsj.com/articles/americas-fading-footprint-in-themiddle-east

[12 ]"Session of the Council of Foreign Ministers from Member States of the Shanghai Cooperation Organisation" (Press release). Kuala Lumpur: Embassy of the Russian Federation in Malaysia. 2007. 


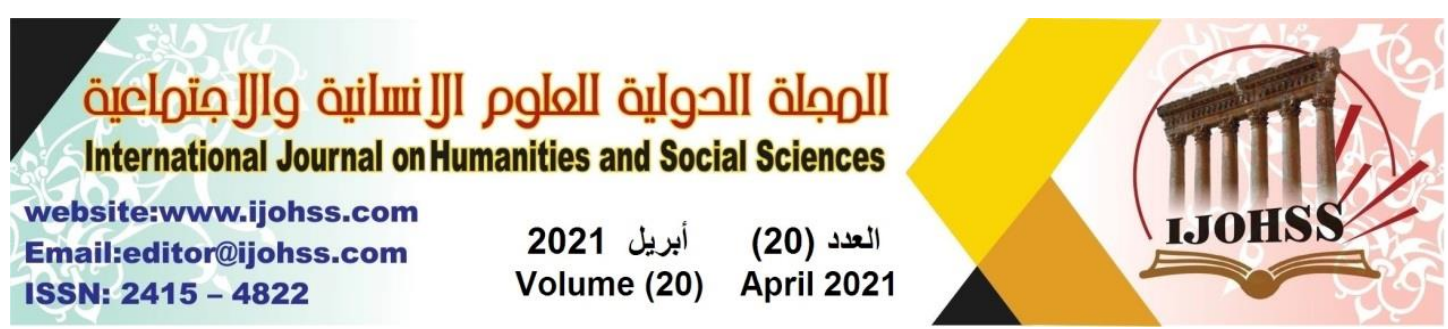

guard exchanges, marine scientific research and rescue, and fisheries. This military cooperation between the two countries can be explained by: ${ }^{[13]}$

A. The desire of the two countries to match India's military progress based on the support of the United States, which uses the Indian paper to permanently put pressure on China as a strategic option, especially after the events of September 11, 2001, and the transition of Indo-"USA" relations to the level of strategic partnership, then signing an "agreement Nuclear cooperation" in the year 2008, which of course irritated Pakistan and China, which is keen on regional balance in South Asia.

B. Standing against the policies of the United States of America seeking to contain the Chinese rise.

C. Pakistan's entry into a race against India for conventional and nuclear armaments, which compels it to search for external partners to provide sources of armament and military technologies.

2-Cooperation in the Nuclear Field: "China-Pakistan" nuclear cooperation dates back to the beginning of the eighties of the last century. In 1986, it was agreed between the two countries to build nuclear reactors in Pakistan, which was called the "China-Pakistan nuclear agreement," which entered into force in 1986. China played a major role in building and developing Pakistan's nuclear capabilities during the eighties and nineties. It supplied Pakistan with many vital components, such as selling them (5000) ring magnets, which are necessary in the centrifuge process of enriching uranium. China also helped build a "Kasma Reactor in Punjab", for research purposes, and equipped with a unit for extracting uranium. Also, during the visit of Pakistani President "Asif Zardari" in October 2008, the two countries signed a cooperation agreement under which China pledged to help Pakistan to enhance its peaceful nuclear capabilities by building two new nuclear reactors in the "Chashma" region. The capacity of each of them is (1100) megawatts. Their construction was completed in 2019. China is building two factories in "Karachi", with a generating capacity of (1100) megawatts from each station. These nuclear plants will reach (3380) megawatts upon full operation. China "helped build six nuclear reactors in Pakistan with a complete production capacity of (3.4) million kilowatts." [14]

The Pakistani-Chinese nuclear cooperation came as a response to US-Indian cooperation in the nuclear and military fields, as well as the geostrategic nature of South Asia in the Chinese strategic perception as it is a geographical neighborhood and a strategic extension of energy resources in the Middle East region. It is worth noting that Pakistan is not a party to the Treaty on the Limitation of Nuclear Weapons

[13] Ma Jiali, Sino-Indian Relations Gain New Moment, Statement, 13 February 2019. https://www.albayan.ae/opinions/articles/2019-02-13.

[14] Ralph Jennings, China Gets Cozier With Pakistan Again And, Yes, India Should Worry ,www.forbes.com,26 Mar 2017. 


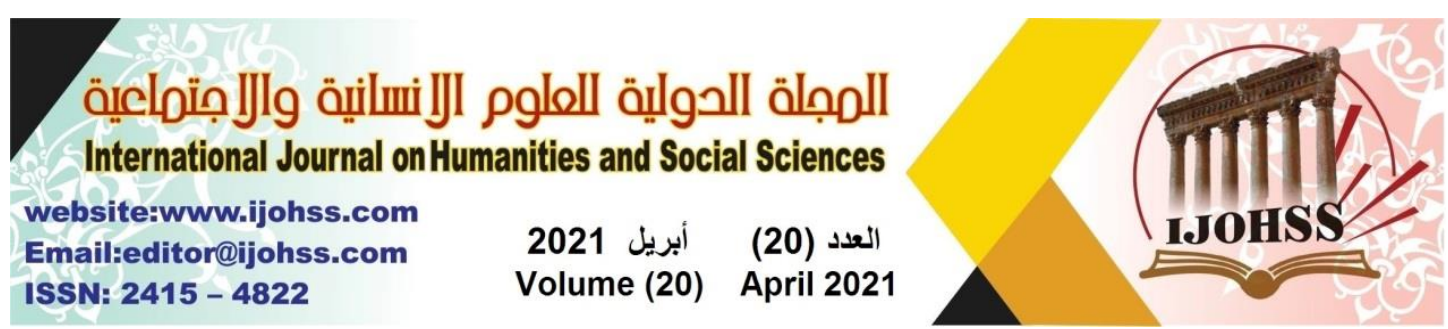

of 1968, and Pakistan's possession of nuclear weapons came in light of the policy of alliances during the Cold War between the communist camps led by the Soviet Union and the capitalist camp led by the United States of America. ${ }^{[15]}$

\section{IV- The Economic and Commercial Impact:-}

1-Economic Cooperation:- The two countries attach special importance to economic cooperation. The political partnership between them is showing concrete results in terms of economic cooperation. Pakistan faces many problems and complications in terms of economic and social development. China contributes to improving the "new blood-making capacity", which is necessary to revive the economy and ensure sustainable development. The "China-Pakistan" partnership is essential for regional development and regional stability in a turbulent environment like South Asia. Bilateral economic projects between Islamabad and Beijing are attracting other regional players to integrate into regional economic projects and blocs, which strengthens the economic interdependence between the regional players, as is the case in the "China-Pakistan Economic Corridor Project", which attracted active countries such as the Russian Federation and Iran to join the project. ${ }^{[16]}$

2- Trade Exchange: With General Pervez Musharraf assuming power in Pakistan (2001-2008), bilateral economic relations entered a new phase. Emphasis is placed on economic cooperation with China ${ }^{[17]}$. During his visit to Beijing in 2001, he stressed the need for joint work and cooperation to expand trade and investment between the two countries to enhance the strategic partnership. In turn, Beijing in 2003 agreed to invest (740) million dollars to build the second "Chashma" project. In December 2004, Pakistan and China signed seven agreements in the sectors of energy, trade, communications and others. The free trade agreement that was signed between the two countries in 2007, during the Chinese President "Hu Jintao's" visit to Islamabad, transferred trade relations to the highest levels, so that the balance of trade between Pakistan and China increased from (1.8) billion dollars in 2005 to four Billions of dollars in 2008. Pakistan's exports to China also rose by about (35\%) annually ${ }^{[18]}$. In 2011, the two countries succeeded in raising the volume of trade exchange between them to (16) billion dollars. China's exports to Pakistan have increased by (10\%) in the past five years. As a result, China's share of total Pakistani exports increased

[15] Ahmad Rashid Malik, Senior Research Fellow, ISSI. The Growing Pakistan-China Defense Cooperation. October 07, 2016.

[16] Web Editor, China-Pakistan Economic Corridor will be a game changer: Nawaz Sharif, www.business-standard.com,27 Mar 2017.

[17 ]Pakistan Calls for Political Solution to Syria Crisis" (2013), Xinhua News Agency, 201309-27. http://news.xinhuanet.com/english/world

[18] Ma Jiali, Sino-Indian Relations Gain New Moment, Statement, 13 February 2019. https://www.albayan.ae/opinions/articles/2019-02-13. 
المجلة الدوالية اللهلور الآنسانية والإمتماعية

International Journal on Humanities and Social Sciences

website:www.ijohss.com

Email:editor@ijohss.com

ISSN: $2415-4822$

العدد (20)

Volume (20) April 2021

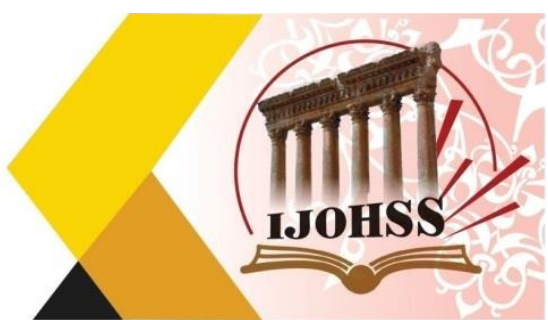

gradually from (4\%) in the year (2009-2010) to (9\%) during the fiscal year (20142015). ${ }^{[19]}$

\section{The Second Topic / Relations Between the Two Countries in the Next Decade}

(2020-2030)

For the purpose of arriving at a clear vision for the future of Chinese-Pakistani relations in the coming decade in the year 2030, which is centered in its entirety in its strategic division, cooperation and economic partnership. It is necessary to know the most important data of the current reality and the prospects for the near future in light of the strategies adopted by China and Pakistan :-

\section{I- "Active Defense" China's new Strategic Vision:-}

Beijing released an official military government report in 2015, which outlined the main points of the new policy of "active defense", and raised perceptions that Chinese forces would play a more global role in protecting the country's interests abroad. These interests include the continuous flow of oil from the Middle East, as China imported about (7.6) million barrels of crude oil per day in the year 2018, more than (70\%) of which came from the Gulf region. For the past decade, the Chinese military presence has been very limited in the Arabian Sea and adjacent waterways, leaving only limited options to protect its interests there. The future Chinese vision of controlling the world's economy translated it into the "Belt and Road Initiative", embodied in China's strategic tendency that might turn into a military one. In 2009, Beijing began its mission to combat piracy in the Gulf of Aden, which enabled it to deploy naval forces in the region to Indefinitely. In 2017, it opened a large naval base in neighboring Djibouti overlooking the strategic strait, Bab al-Mandab, claiming to contribute to the security and development of the region, including the construction of a railway to Ethiopia, which does not have a seaport. Besides the base of the Pakistani "Jiwani Port" on the Gulf of Oman, the base of Djibouti may give different importance. The two bases will place Chinese forces at the entrance of two strategically vital international waterways, which could allow China to restrict the movements of its opponents in the region as part of a more comprehensive "denial of access strategy" than the "A2 / AD" strategy that the Chinese call "strategic counterattacks Active on external fonts" or "ASCEL". [20]

[19] Pakistan-China Relations in Response to Common Challenges and Opportunities, Building, No. 2398, June 2017: http://www.al-binaa.com/archives/article/168029.

[20] Farzin Nadimi, A China-Pakistan Base Building Deal May Harm Iranian Interests, The Washington Institute, Political Observatory, Issue (2948) March 27, 2018. 


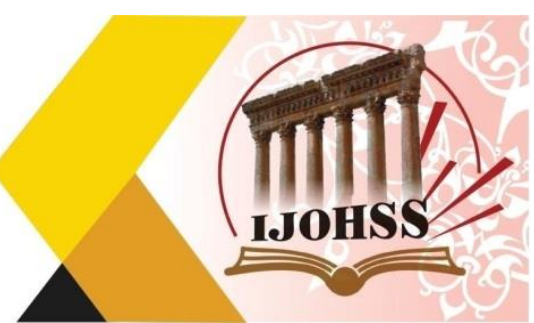

\section{II- China adopts a Policy of Void Space in Pakistan:-}

Beijing hopes to make its relations with Islamabad more flexible, which is what its signs have begun to emerge. Pakistan has realized that it needs a partnership and an alliance with China in the wake of India's alliance with the United States, and it has received signs of uneasiness and resentment by the US government against the background of the war file On terrorism. After "Trump's tweets", China managed to get what it failed during a series of attempts, as the Central Bank of Pakistan announced that it had opened the door to dealing in "Chinese yuan" in the country's imports, exports and investments. This in itself expresses a major transformation in light of the construction of roads, power stations, dams and railways linking the two countries, which led to a doubling of their trade exchanges, which was translated by an increase in the value of the two countries' trade value from four billion dollars in 2007, To (13.7) billion in 2016, a boom that accelerated its pace with the launch of the "Economic Corridor between China and Pakistan" in May 2015, which includes (37) special economic zones, and connects "Shen Jiang" in western China to "Gawadar Port" The Pakistani near the Iranian port "Chabahar". [21]

\section{III- The Arrival of a new leadership in Pakistan Seeking new Alliances to chart a better Future:-}

With the arrival of "Imran Khan" to power in Pakistan in the year 2018, he tried to consolidate his external relations with Iran, China, Turkey and Malaysia, trying to pull Pakistan out of the deteriorating economic situation resulting in the signing of several strategic partnerships in the economic sector, nuclear energy and armament. Pakistan seeks to achieve balance in international relations, after the United States adopted the consolidation of its relations with India after the collapse of the Soviet Union, which means a change in priorities for the American administration, which started to put pressure on Pakistan with the file of armed groups, so the issue of Pakistan-China relations is one of the most important reasons Relations between Pakistan and the United States are strained, given that Beijing began looking to develop a development vision through the "Pakistani Road Map in 2025", and linked it with the "China Silk Road Economic Project", which Pakistan sees as an opportunity, as the China project will enable it to establish Extensive road networks, port, marine trade lines, airports and railways, which contribute to improving the

https://www.washingtoninstitute.

org/ar/policy-analysis/view/a-china-pakistan-base-dealcould-put-iran-on-the-back-foot.

[21] Awad Khairi, Pakistan takes refuge in Russia and China instead of Washington, February 2018, https://www.emaratalyoum.com/politics/reports-and-translation. 


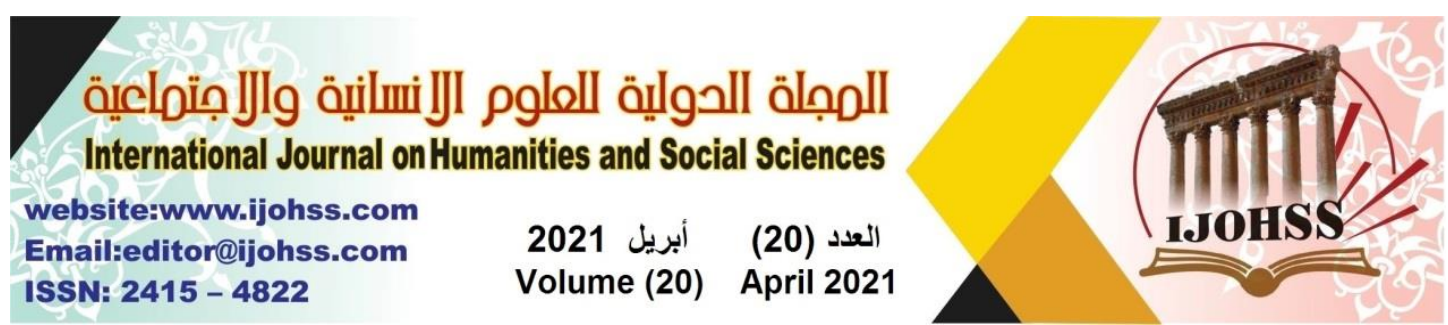

internal economic situation, as it will create job opportunities that provide a steady income for the unemployed in the regions where transport lines will pass, eliminate the incubators of extremist thought, and also enhance Pakistan's ambition at the regional level. ${ }^{[22]}$

\section{IV- The Escalation of Pakistan's Role at the Regional Level:-}

After accepting Pakistan in July 2015, as a permanent member of the "Shanghai Cooperation Organization", Pakistan's regional importance as a determining factor for peace and security and effective cooperation between member states and observer states in the organization has increased. This membership means a lot to Pakistan, because if it wants to become an energy corridor through Russian support, it must have a healthy relationship with India, and this is what Pakistan hopes to achieve by accepting India's membership in the "Shanghai Organization" and sitting at the same table. The importance that Pakistan attaches to the "Shanghai Cooperation Organization" is based on its ability to become a commercial corridor that brings life to the landlocked Central Asian republics and the "Xinjiang" region in western China. Pakistan's entry into the organization will greatly enhance its position in the region and the world and will have a positive impact on many major issues related to military and technical cooperation between Russia and Pakistan and mega communication projects with China. With the ongoing plans to link the "Silk Road Economic Belt" with the European Union, Pakistan, Kyrgyzstan and Tajikistan have signed an agreement on electricity exports from Central Asian countries. Moreover, Pakistan, China, Kazakhstan and Kyrgyzstan have agreed to start bus service for ground transportation. These positive developments, along with the "Gawadar Port" project, make Pakistan an indispensable link for the Organization member states. The "Shanghai Cooperation Organization" membership can also pave the way for the completion of the Turkmenistan, Afghanistan, Pakistan, India gas pipeline and the Central Asia and South Asia electricity transmission and trade project known as the "Casa 1000". It is also estimated that Pakistan will be able to attract significant investments in the energy and infrastructure sectors in which the "OIC" countries enjoy. So the role of Pakistan in the regional economy and infrastructure projects in the next decade will definitely increase. $\left[{ }^{23}\right]$

[22] Middle East Online, Pakistan bets on Chinese aid to avert financial crisis: Pakistani Prime Minister meets his Chinese counterpart, seeking aid and investment from the world's second largest economic power. 11/03/2018. https://middle-east-online.com.

[23 ] K J M Varma, Entry of India and Pakistan in SCO will contribute to regional stability: China, http://www.livemint.com,14 Mar 2017. 
website:www.ijohss.com

Email:editor@ijohss.com

ISSN: $2415-4822$
العدد (20) ( أبريل 2021

Volume (20) April 2021

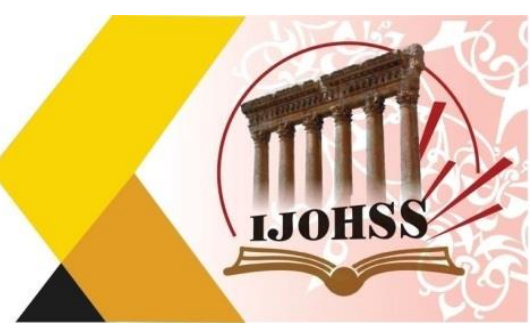

\section{V- China-Pakistani joint projects:-}

1- China-Pakistan Economic Corridor "CPEC":- The project will create economic opportunities for both Pakistan and the member states of the "Shanghai Cooperation Organization", which will bridge the gap between the continents, and connect China and Pakistan to Central Asia, the Caucasus and Russia. At the end of 2017, the long-term "China-Pakistan Economic Corridor" plan (2017-2030), which was approved by the governments of the two countries, was announced. The plan links the "Belt and Road" initiative with "Pakistan's Vision 2025". The project is the most prominent of what Pakistan and China reached on the level of bilateral economic relations during the visit of Pakistani Prime Minister "Nawaz Sharif" to Beijing in the second half of 2013, considering this project the biggest achievement for Pakistan after the nuclear bomb, describing the project as "Game changer". The "CPEC" is a group of infrastructure, energy, transportation and industrial cooperation projects along the area stretching from the area bordering southern China, "Kashgar-Xinjiang", and the "Gulght-Baluchistan" region, in northern Pakistan, to the far southwest of Pakistan in "Gwadar port" overlooking the waters of the Arabian Sea. The project includes the completion of "Gwadar International Airport". The project also includes the expansion of the "Karakoram" Highway. According to expectations, the "Economic Corridor Project" will create about (700) thousand direct job opportunities during the period (2015-2030), and it will add up to $(2.5 \%)$ to the growth rate of Pakistan. ${ }^{[24]}$

The project carries great strategic importance, with an estimated investment volume of (46) billion dollars. (29) industrial cities will be built along the path of the corridor, which will secure many job opportunities. Achieving economic development and increasing the level of prosperity in the country. And a system for generating electricity that includes securing energy sources from coal, sun, water, and wind, in projects that complement the economic corridor project, especially the solar energy and coal energy projects, and work is being done to establish lakes on waterways and establish hydroelectric stations, which will contribute when entering the stage of generating electricity Of them, the cost of electricity in the country will decrease significantly. It is expected that the international road that will connect the two countries will contribute to the rise of many Pakistani cities, such as the capital "Islamabad, Lahore, Peshawar, Multan, Hyderabad, and Karachi". Through the project, China will be able to halve the length of the road from the Strait of Malaga to the European sea route, and will achieve annual profits of at least (\$10) billion. While

[24] The Egyptian Center for Strategic Studies and Research, Sino-Pakistani Relations, 17 July 2018. http://efsregypt.org. 


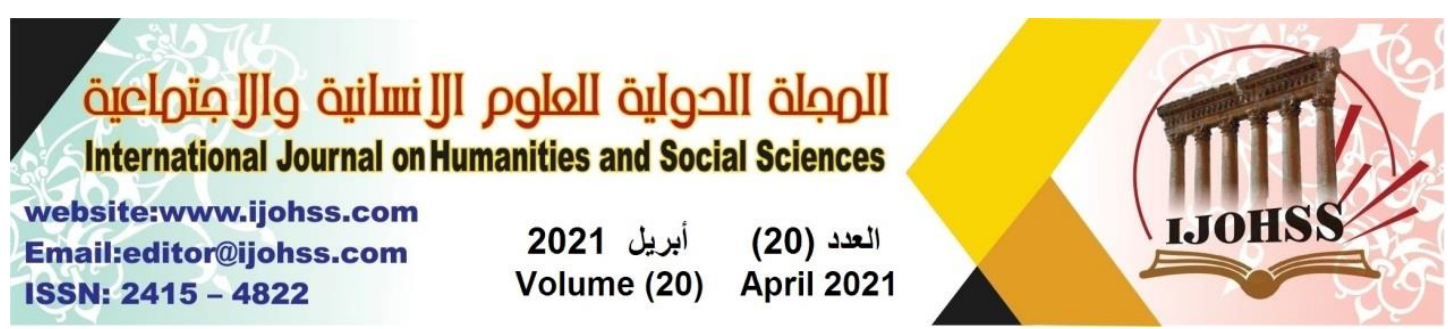

Pakistan is expected to achieve profits from the international road worth five billion dollars annually. And it will play a role in achieving growth mainly for Beijing and Islamabad. In addition, the project links Russia, Mongolia and the rest of Central Asia with the Gulf of Hormuz, which means that it will change the balance of international powers in the region. ${ }^{[25]}$

Pakistan is counting heavily on this project to boost economic growth through improving infrastructure and solving the energy problem, as economic growth rates reached $(7 \%)$ in 2018, which is the largest investment that Pakistan has attracted since its separation from India in 1947, and the largest foreign investment for China Absolutely. Since the launch of the "China-Pakistan Economic Corridor" projects, it has received support from all walks of life in Pakistani society. In January 2019, Prime Minister of Pakistan "Imran Khan" indicated that completed "CPEC" were in the interest of Pakistan, and would provide the Pakistani people with great opportunities for social and economic development. The two countries intend to enhance bilateral relations through this huge investment plan, and the project will ensure that Pakistan becomes a regional economic center, especially as Pakistan lies at the intersection of three growth engines in Asia:(South Asia, China and Central Asia), and the "CPEC" will help integrate these regions. To become one economic zone. ${ }^{[26]}$

Seven energy projects were launched in 2018, with a total electricity generation capacity (5.19) billion kilowatt hours per year, and with investments amounting to (1.5) billion dollars. It is expected to meet the electricity demand of about (6.8) million Pakistani families. There are five other projects to generate energy under construction with a total investment of (2.8) billion dollars, and in the field of transportation, three projects have started with a total investment of (8.5) billion dollars. There is also an agreement to deepen cooperation between the two countries to improve the livelihood of the local population, including cooperation in the fields of agriculture, education, health care, water supply, poverty alleviation and vocational training. In order to speed up the manufacturing process in Pakistan, the two sides have promoted the comprehensive construction of "Gawadar" and accelerated construction of the new international airport, seawater desalination plant, ChinaPakistan Friendship Hospital and vocational school, among others. ${ }^{\text {[27] }}$

[25] Zarar Genghis, China-Pakistan Economy Corridor .. Project that changes international balances: The project carries great strategic importance with an estimated investment of $\$ 64$ billion, Anatolia, Istanbul, 11/28/2018: https://www.aa.com.tr/ar.

[26] Pakistan reassures China: "Common economic corridor" is safe. New Gulf newspaper, September 9, 2018: https://thenewkhalij.news.

[27] Zhang Hui, China-Pakistan Economic Corridor: Model for Building a "Belt and Road", China Today, 4/23/2019: http://www.chinatoday.com.cn/ctarabic. 
المجلة الدوالية اللهلور الآنسانية والإمتماعية

International Journal on Humanities and Social Sciences

website:www.ijohss.com

Email:editor@ijohss.com

ISSN: $2415-4822$

أبريل 2021

(20) العدد

Volume (20) April 2021

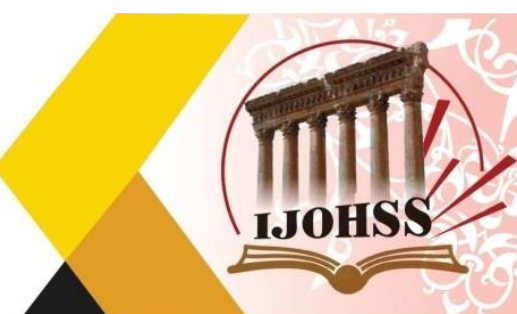

2- The "Gawadar Port" project:- The "Pakistani port of Gwadar" is located on the Arabian Sea near the "Strait of Hormuz" in southwestern Pakistan, but at the same time it ignited a cold war between many countries, led by the Emirates, India and America on the one hand, China, Pakistan, Qatar and Russia on the other. The port is part of the "One Belt and One Road" project announced by China in 2013, in the context of its continued rise as a great economic power, and the project is a group of giant sea and land roads, which will be established during a time plan in cooperation with (68) countries with the aim of delivering Chinese goods directly to the world, and the importance of "Gawadar Port" lies in its closeness to China, as it is the closest port to the "Xinjiang" industrial region, when compared to the Chinese ports located in the east, so Chinese trade will cross over land along the geography of Pakistan through the roads that were built until You reach "Gawadar", and from there the goods are transported to Gulf states and the Middle East. ${ }^{[28]}$ What enhances the importance of the port, its strategic location in southwest Pakistan, where it overlooks the Arabian Sea near the "Strait of Hormuz", through which a third of the world's oil trade crosses, and the port's location helps in reducing time and money on commercial flights, and the port's location is of other strategic importance for its location between the south Central Asia and the Middle East, as well as an important part of the ancient "Silk Road" connecting China with Europe, Asia and Africa. Previously, the "Gwadar Port" was under the control of the Sultanate of Oman until it was restored to Pakistan in 1958, and it remained idle until 2002, before the start of Pakistan. Take advantage of the depth of its water and its suitability to receive Large ships. It is intended to become one of the largest ports of its kind in the world, able to deal with the planned Chinese fleet of aircraft carriers and large nuclear submarines. The new port will be able to handle a load of up to (400) million tons annually when it operates at full capacity. ${ }^{[29]}$

With a total cost of the project estimated at about (46) billion dollars. In March 2018, the "Gawadar and Middle East Maritime Navigation Line" for container ships was officially launched, achieving the goal of developing "Gawadar Port" to be linked to the major international ports. In March of the year 2019, the construction project for the new "Gwadar" International Airport officially started. In addition, in January 2018, the first phase of the "Gwadar" Free Trade Zone opened, after two years of construction, with a total investment of (150) million dollars. The first stage of this

[28] Grass Ghazwan, the Pakistani port of Gwadar, a Chinese project threatening the demise of Dubai Ports within 10 years, Al-Adasah, November 2017, http://thelenspost.com/2017/11. [29] "Gwadar port: 'history-making milestones". Dawn. 14 April 2008. 


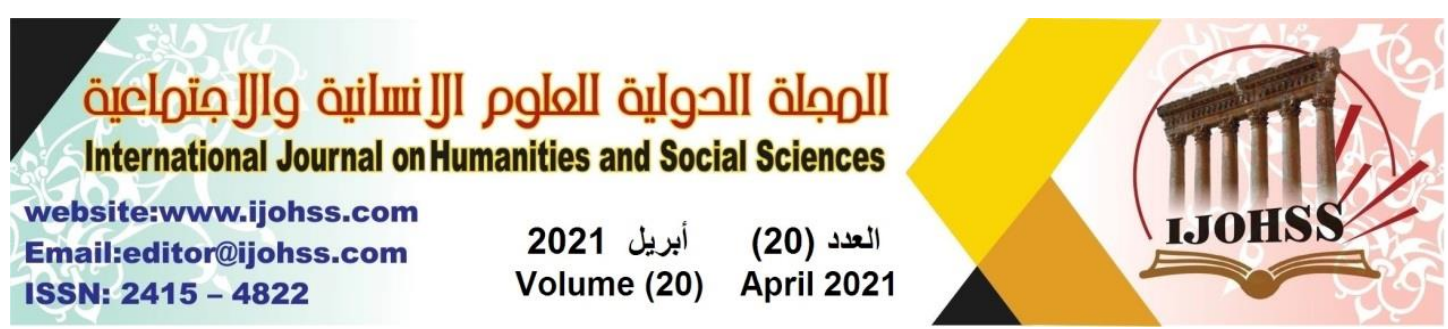

project attracted nearly three billion "yuan", and the free trade zone is expected to provide ten thousand jobs for the "Gwadar" region, and an annual production value of one billion "yuan" after the completion of the construction of the whole project. The China Holding Company for Commercial Ports Ltd. is actively With her social responsibility in Pakistan. Since May 2018, providing $(300,000)$ gallons of fresh water per day to local residents, which has greatly reduced the water supply shortage of the local population. With the help of Chinese charities, the company has completed the construction of schools and medical emergency centers in the "Gawadar" area. Consequently, the region has turned into a relatively safe place for investment, in addition to the drop in crime rates to almost zero rates. ${ }^{\text {[30] }}$

\section{3- "Pakistan's Vision 2025":-}

It is the broad vision and developmental map adopted by the Pakistani government for comprehensive economic growth for the development of Pakistan. If the "ChinesePakistani economic corridor" for Pakistan is a comprehensive strategic project, then the "Pakistani Vision for the year 2025" is the comprehensive vision that aims to make Pakistan one of Asian economic tigers. And access to integrated regional connectivity through: ${ }^{[31]}$

- Establishing a link between four regions: China, South Asia, Central Asia and the Middle East.

- Establishing a permanent communication system, effective transportation, freedom of progress in commercial and economic growth, and the expansion of markets.

- Establishing an internal, dynamic linking system that facilitates communication between the regions of Pakistan through highways and railways.

- Establishing an integrated high-level network of railways and highways between economic centers

Consequently, we find that there is complementarity, convergence, and observance of all the goals of the two future projects, "China-Pakistan Economic Corridor" and "Pakistan's Vision 2025", from the establishment of highway networks and a high-level port, as well as marine general commercial lines, airports, railways and optical fiber cables, to connect Pakistan regionally and make it As a commercial and economic hub, China plans to spend (55) billion dollars in Pakistan on infrastructure projects as part of its plan to build a network of trade routes around the world.

[30] Pakistan-China Relations: Responding to Common Challenges and Opportunities, AlBenaa Electronic Newspaper, $10 \backslash$ June $\backslash 2017$ : https://www.al-binaa.com/archives/article.

[31] Pakistan in Arabic, the China-Pakistan Economic Corridor in Pakistan's Vision 2025, 4/24/2018: http://arabic.pk/2134. 


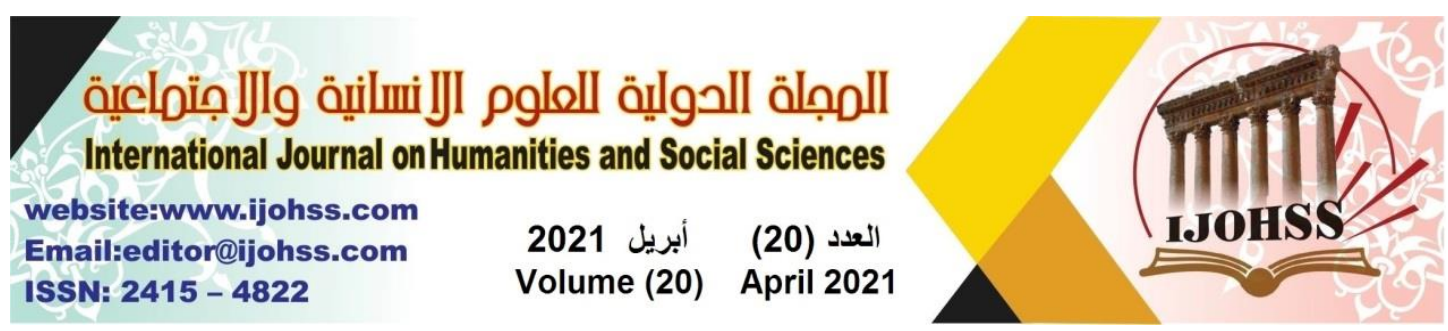

\section{VI- The Regional Position:-}

The geostrategic location of the Pakistani "Gawadar Port" occupies an important place in the economy and international politics, especially after China entered the heart of the event strongly as a major partner for the project, and in the long term a military partnership, it will change the balance of power, and make the Chinese military presence in the region have a greater weight, and magnify the role of China in Global trade, energy diplomacy and political relations, and the damage will be limited to certain ports in the region, and making Chinese energy purchases an opportunity for some countries to diversify their markets, reduce their dependence on the United States, and protect their profits by investing in the oil refineries sector in China, as the distance between "Gawadar Port" and "Port of Muscat" in the Sultanate of Oman is about (385) km, and this has a strong relationship with gas exports through the Strait of Hormuz, and this is linked to "Gawadar Port" and the thinking of the exporting countries is more serious now to establish stations Oil and gas abroad, and therefore Qatar contributes to financing the development of "Gawadar Port" to direct its strike at the ports of its neighbors, while providing the gas that China needs for its rapid growth, which in turn will certainly lead to the restructuring of some Gulf countries for their political and commercial priorities, and the time that will be Its provision would give the Gulf and Chinese companies a comparative competitive advantage On other international companies and foreign investment, and attracting foreign companies, tourism and trade may go towards Pakistan after China completes its projects in Pakistan, and seriously strive for the rapid development of the free zone and industrial areas in the port, and that region may have evolved to impose a strong economic impact that threatens the strategic impact of traditional areas of trade in The Persian Gulf. This will inevitably be followed by a Chinese naval presence in "Gawadar" to patrol the sea lanes in the Indian Ocean, which will concern Washington and New Delhi about the Chinese naval presence near the "Strait of Hormuz", to cross Chinese trade by land. Pakistan through the roads created to reach "Gawadar", and from there the goods are transported to the Gulf countries and the Middle East. ${ }^{[32]}$

On the other hand, the project of developing "Gawadar Port" will enhance the close cooperation between India and the Arab Gulf countries for fear of passing the ambitious Chinese project in the disputed "Kashmir" region with Pakistan, which means that the region will be subject to Chinese protection after it becomes a passage for its goods, in addition to the establishment of this pass The economic situation of Pakistan, which India fears without complaint, and India, in cooperation with the Gulf

[32] Pakistan in Arabic, the importance of the China-Pakistan economic corridor to change the dynamics of the region, entry date: 24/4/2018: http://arabic.pk/2137. 


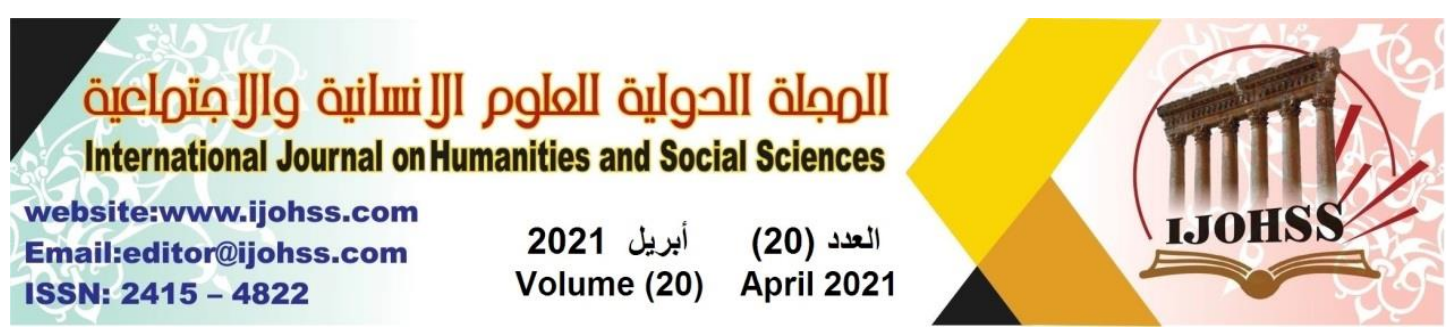

states, especially the "UAE", has accelerated the development of the Iranian "Chabahar Port", which is located $(165 \mathrm{~km})$ away from "Gawadar" to turn the conflict between Pakistan and India into a frantic race to complete its project, as it is an extension Additional leverage The Russians in Central Asia are also ahead of their American rivalry, and given Pakistani interlocking interests, betting on Pakistan may seem like an Arab bet on the long run. ${ }^{[33]}$

While China is ready to support Pakistan in the face of India, it is concerned that India's attitude towards the demonstrations in Hong Kong will shift from neutrality to supporting the demonstrators. Opening more fronts of conflict with India will have a very high cost, especially as China deals with a number of very serious and sensitive local and global issues, especially the protests in some of its regions, and the trade war with the United States of America. China also wants to complete its plans for the "Belt and Road" initiative. India has spared no effort to announce its opposition to the "CPEC" project, which has aroused its ire. Therefore, any violence in this region will hinder China's plans to complete its projects. China is likely to pressure Pakistan not to resort to any violent escalation against India, and China will benefit from strengthening its role and image as a country that maintains balance in South Asia. ${ }^{\text {[34] }}$

Pakistan's advanced position in China will remain unchanged for a long time, despite the recent improvement in relations between China and India, in an era of growth and focus on "setting aside differences" for the benefit of future generations. From a distance perspective, China will take into account two types of interlocking factors:- ${ }^{[35]}$

1- The contradictions between the Indo-Chinese economic cooperation, and the Chinese perception of the threat and military preparedness accounts in the country.

2- India's strong awareness of the United States' concerns regarding the development of China as a potential superpower, hence the qualitative progress in cooperation between India and the United States.

\section{VII- The International Position:-}

In the wake of the deterioration in "Pakistani-American" relations following the American actions in striking "al-Qaeda" leaders in Pakistan without reference to them in the context of its campaign against what it calls "safe havens for terrorists" inside Pakistani territory, this event raised Pakistani concerns that India would take measures

[33] Scuserev, Pakistan May Become a Chinese Colony, Nizavisimaya Gazeta Newspaper, 6/20/2017: www.addiyar.com.

[34] Ridha Muhammad Hilal, China and Pakistan, close relations, Journal of International Politics, July 2017, Date of entry: 4/22/2018, http://www.siyassa.org.eg/News/1589.aspx.

[35] Shashi Tharoor, India's problem with China in Pakistan, the new morning, $18 \backslash$ March 2019: http://newsabah.com/newspaper/180060. 


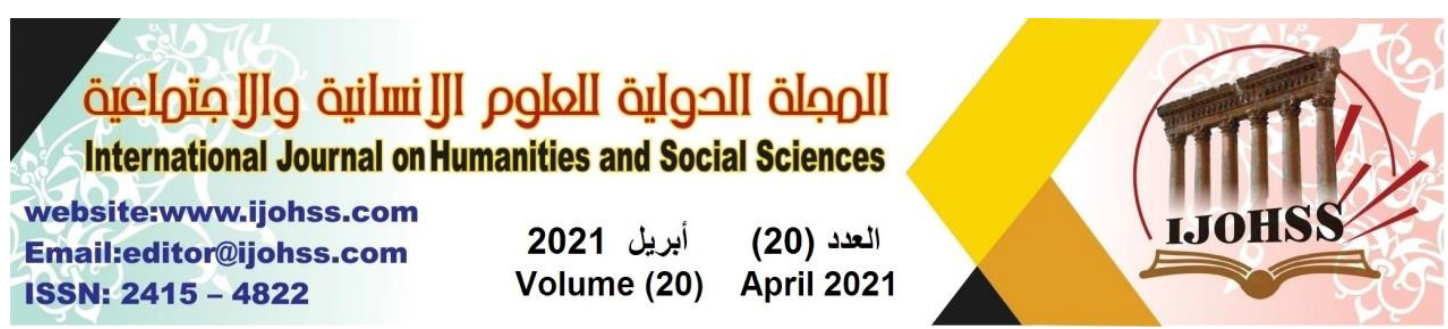

to pursue a similar policy, especially as India Pakistan is accused of recruiting or harboring "Kashmiri" militants carrying out terrorist operations inside India. Against the backdrop of the agreement between the United States and India to transfer civilian nuclear technology, India is witnessing a rise as a regional domination that linked to major international players, with See her at work to undermine Pakistan's ability to maneuver in the international arena. We find that China supports Pakistan through active cooperation in the field of nuclear energy generation, and the recent agreements to establish two nuclear power plants are the most prominent evidence of this. However, Pakistan's participation in the "global war on terror" "which affects the social fabric of the country and its institutional and economic strength" will continue to be a continuous phenomenon, at a time when the United States will not stop demanding more Pakistani efforts. As India continues to rise as the enemy of Pakistan and traditional China, the China-Pakistan alliance will be more realistic than ever. ${ }^{\text {[36] }}$

The Indian and American opposition to the "CPEC" project may be one of the main reasons that it will lead to reducing the American role in the Indian continent and South Asia at the expense of the rise of China as an economic power linking the three continents of the world. "USA" to create chaos in the border triangle near the "Silk Road" and "Gwadar Port", with the aim of blocking the project by raising the pace of the actions of armed groups in the disputed areas. On the other hand, China is aware of the seriousness of the development of the "Indo-American" relations on its southern borders and on its interests and relations in its regional surroundings, especially while retaining the eastern part of Kashmir, in addition to concerns about the future of "Tibet" about any Chinese abandonment of the part that is subject to it in "Kashmir". To raise her domestic problems while continuing to claim independence with "USA" support. Which prompted China to stick to the option of high diplomacy in dealing with India on the issue of border problems without resorting to the option of escalation or threatening military tone so far. ${ }^{[37]}$

With the emergence of the "Chinese-Pakistani-Iranian" rapprochement, a "USAIndian-Israeli" resentment appears on the opposite side, as America strongly opposed the Iranian gas project to be delivered to Pakistan and China, as it conflicts with its project to export liquefied gas to East Asia, and the Iranian project will reduce the importance of the gas agreement The United States signed with India in 2018, to export its ( Liquefied gas "LNG") for twenty years. The United States also opposes the Russian gas project, which aspires to build a gas line from the Caspian Sea to

[36] Abdul Majeed Bhatti, Pakistan Pakistan's Dilemma: severing ties with America in favor of China !, Al-Raya Newspaper (Hizb ut-Tahrir), Pakistan, January 17, 2018: http://www.alraiah.net /index.php/political-analysis/item/3087.

[37] Yaman Debki, Conflict over Kashmir (Multiple Crises and Future Dimensions), Buraq Politics Network, September 9, 2019. https://barq-rs.com. 


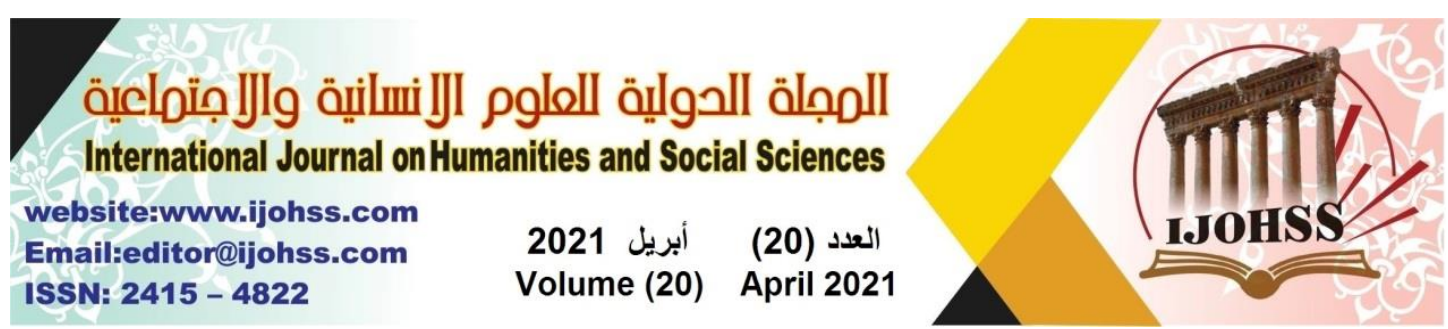

India passing through Pakistan. So "US" President "Donald Trump" has imposed an economic blockade on both China and Iran, in an attempt to force them to negotiate and accept new trade rules. ${ }^{[38]}$

\section{Results:}

In light of what has been presented about the development stages of "ChinaPakistan" relations and the stages of cooperation at all levels, especially in the economic and military fields, and the positions of effective and influential countries, the future of relations between the two countries in the next decade in 2030: -

1- "China-Pakistan" relations are described as "friendship appropriate to all circumstances," because of Pakistan's geographical and political location, which is located at a crossroads between Central Asia, South Asia and West. This friendship represents a bulwark against the encirclement of China, and a bridge for its trade communication with the Arabian Sea.

2- The "China-Pakistan" strategic relationship is based on mutual respect for the "vital interests" of both sides: according to the equation of China's steadfast support for Pakistan's independence, sovereignty and territorial integrity. On the other hand, Pakistan's firm adherence to the unified China policy and opposition to any separatist tendencies, whether related to "Tibet or Xinjiang".

3- Chinese assistance to Pakistan with a focus on achieving "self-reliance" and "without conditions", such as implementing mega projects.

4- China is on the way to becoming the strongest partner of Pakistan, which raises the concerns of the United States of America about the possibility of shifting its relationship with Pakistan in favor of China, which was confirmed by some officials in Pakistan, as Pakistan seeks to deepen its relationship with China and obtain support from Beijing so that it can Face Washington.

5- As for the "Chinese, Pakistani, and Indian" border dispute file, there are strong factors pushing the two parties to the conflict, Pakistan and India, to adhere to the Kashmir region and maintain its current status.

6- It is likely that "China-Pakistan" relations will remain in a state of sustainable development, and in return, all regional and international parties will work to stand in the way of China-Pakistani projects.

7- The United States of America is moving in a practical way to encircle the economic and commercial influence of China, and is trying to prevent the "Silk Road" project, and push India to raise some ethnic problems in the adjacent regions, to provoke conflicts in the border triangle (China - Pakistan - Afghanistan).

[38] Sarmad Ashfaq, How does America plan to block the China-Pakistan economic corridor? 13/06/2019 source. https:// Open Democracy. 


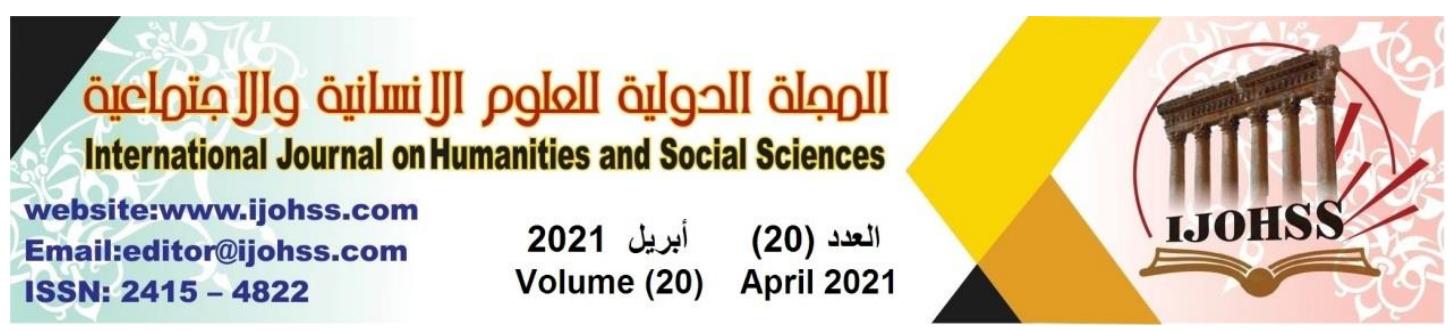

8- China will seek to find vital alternatives that give it economic and political gains, relieve it from the pressure of the US geopolitical blockade on it in the region, and accordingly, the US-Chinese competition in the Asian gate has not yet completed its chapters and will remain in the context of escalation.

\section{Conclusions:}

1- "China-Pakistan" relations were able to wisely transcend the two regimes of government. Beijing adopts the communist ideology, while Islamabad adopts an Islamic republic system. The evolutionary context of the history of the relationship between the two countries has proven that they have managed throughout the period extending from the fifties of the last century to the present day to preserve and deepen this relationship.

2- The relations between China and Pakistan in South and Central Asia tend to be a logical and justified response to many regional problems with a state of political instability as well as an economic recession. There is no dispute that cooperation between China and Pakistan will lead to strengthening bilateral relations, which will necessarily push for regional growth in the region with the expectation of economic prosperity, since China is one of the emerging economic powers and therefore strengthening relations between it and Pakistan will be in the region's interest. all of which.

3- The "China-Pakistan" rapprochement, after announcing in 2017 the long-term "economic corridor" plan that will continue until 2030, and linking the "Belt and Road Initiative" with the "Pakistan Vision 2025". Economic cooperation is a milestone in the bilateral relations between the two countries.

4- The two countries focus on practical and economic cooperation with serious work to reach political partnership in the form of results from cooperation in the economic reality, which is cooperation that represents a serious step in the main interests between China and Pakistan.

5- The military, security, defense and economic relations between the two countries are necessary to maintain peace and stability in the region.

6- The digital economy and cyber security are no less important, with the need for cooperation between the two countries to face the emerging challenges in these important areas and in the field of the Internet. 


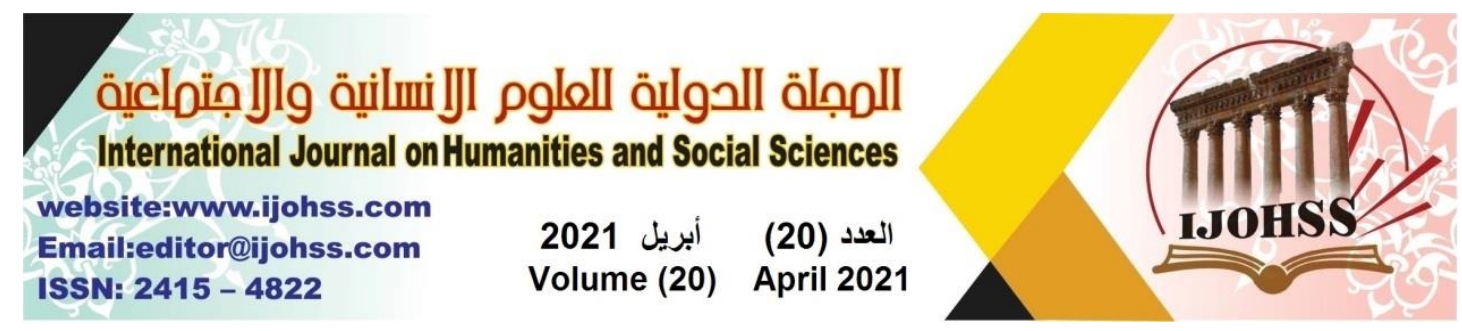

\section{References}

1. Abdul Majeed Bhatti, Pakistan Pakistan's Dilemma: severing ties with America in favor of China !, Al-Raya Newspaper (Hizb ut-Tahrir), Pakistan, January 17, 2018 : http://www.alraiah.net /index.php/political-analysis/item/3087.

2. Ahmad Rashid Malik, Senior Research Fellow, ISSI. The Growing PakistanChina Defense Cooperation. October 07 , 2016.

3. Associated Press of Pakistan, Pakistan and China relations: 65 years of friendship to strategic partnership,www.pakistantoday.com.pk,15 May 2016.

4. Associated Press of Pakistan, Pakistan and China relations: 65 years of friendship to strategic partnership,www.pakistantoday.com.pk,15 May 2016.

5. Awad Khairi, Pakistan takes refuge in Russia and China instead of Washington, February 2018, https://www.emaratalyoum.com /politics/reports-and-translation.

6. Chinese military base in the Pakistani port of Gawadar, New Gulf, January 8, 2018. https://thenewkhalij.news/index.php/article.

7. Farzin Nadimi, A China-Pakistan Base Building Deal May Harm Iranian Interests, The Washington Institute, Political Observatory, Issue (2948) March 27, 2018. https://www.washingtoninstitute. org/ar/policy-analysis/view/a-china-pakistanbase-deal-could-put-iran-on-the-back-foot.

8. Grass Ghazwan, the Pakistani port of Gwadar, a Chinese project threatening the demise of Dubai Ports within 10 years, Al-Adasah, November 2017, http://thelenspost.com/2017/11.

9. Gwadar port: 'history-making milestones". Dawn. 14 April 2008.

10. John Garver (2016), "China and Iran: An Emerging Partnership Post-Sanctions, "Middle East Institue, 2016 -02 -08. http://www .mei.edu/content/china-and-iranemerging-partnership-post-sanctions.

11. K J M Varma, Entry of India and Pakistan in SCO will contribute to regional stability:China, http://www.livemint.com,14 Mar 2017.

12. Ma Jiali, Sino-Indian Relations Gain New Moment, Statement, 13 February 2019. https://www.albayan.ae/opinions/articles/2019-02-13.

13. Middle East Online, Pakistan bets on Chinese aid to avert financial crisis: Pakistani Prime Minister meets his Chinese counterpart, seeking aid and investment from the world's second largest economic power. 11/03/2018. https://middle-eastonline.com.

14. Pakistan Calls for Political Solution to Syria Crisis" (2013), Xinhua News Agency, 2013-09-27. http://news.xinhuanet.com/english/world.

15. Pakistan in Arabic, the China-Pakistan Economic Corridor in Pakistan's Vision 2025, 4/24/2018: http://arabic.pk/2134. 


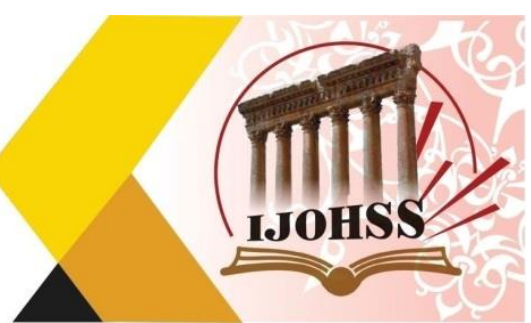

16. Pakistan in Arabic, the importance of the China-Pakistan economic corridor to change the dynamics of the region, entry date: 24/4/2018: http://arabic.pk/2137.

17. Pakistan reassures China: "Common economic corridor" is safe. New Gulf newspaper, September 9, 2018: https://thenewkhalij.news.

18. Pakistan-China Relations in Response to Common Challenges and Opportunities, Building, No. 2398, June 2017: http://www.al-binaa.com/archives/article/168029.

19. Pakistan-China Relations: Responding to Common Challenges and Opportunities, Al-Benaa Electronic Newspaper, $10 \quad \mid$ June $\mid$ 2017: https://www.albinaa.com/archives/article.

20. Qahtani Mutlaq (2006). "The Shanghai Cooperation Organization and the Law of International Organizations" (PDF). Chinese Journal of International Law. Oxford University Press. 5 (1): 130. ISSN 1540.

21. Qasim Muhammad Jaafar, The Fourth Nuclear War in the Indian Subcontinent, Al-Wasat Magazine, No. 173, London, 1995, p. 38.

22. Ralph Jennings, China Gets Cozier With Pakistan Again And, Yes, India Should Worry ,www.forbes.com,26 Mar 2017.

23. Ridha Muhammad Hilal, China and Pakistan, close relations, Journal of International Politics, July 2017, Date of entry: 4/22/2018, http://www.siyassa.org.eg/News/1589.aspx.

24. Sarmad Ashfaq, How does America plan to block the China-Pakistan economic corridor? 13/06/2019 source. https:// Open Democracy.

25. Scuserev, Pakistan May Become a Chinese Colony, Nizavisimaya Gazeta Newspaper, 6/20/2017: www.addiyar.com.

26. Session of the Council of Foreign Ministers from Member States of the Shanghai Cooperation Organisation" (Press release). Kuala Lumpur: Embassy of the Russian Federation in Malaysia. 2007.

27. Shashi Tharoor, India's problem with China in Pakistan, the new morning, $18 \backslash$ March 2019: http://newsabah.com/newspaper/180060.

28. Shen Yahsin (2015), "China-Pakistan Relations in Xin Jinping's Eye", People's Daily Online, 2015-04-17. http://politics.people.com.

29. Takungpao.com 2014/05/05 http://finance.takungpao.com.hk/hgj.

30. Tariq Ali, Kissinger visit to China 1971, http://historypak.com,07 jun 2006.

31. The Egyptian Center for Strategic Studies and Research, Sino-Pakistani Relations, 17 July 2018. http://efsregypt.org.

32. Web Desk. Pakistan Receives LD-10 Anti-Radiation Missiles From China, http://pakchinanews.pk, 23 Aug 2006.

33. Web Editor, China-Pakistan Economic Corridor will be a game changer: Nawaz Sharif, www.business-standard.com,27 Mar 2017. 


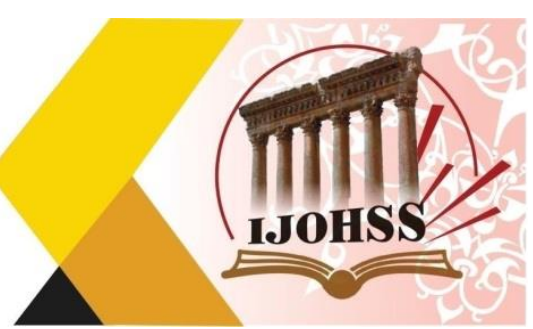

34. Yaman Debki, Conflict over Kashmir (Multiple Crises and Future Dimensions), Buraq Politics Network, September 9, 2019. https://barq-rs.com.

35. Yaroslav Trofimov (2015), "America's Fading Footprint in the Middle East," The Wall Street Journal, 2015-10-09. http://www.wsj.com/articles/americas-fadingfootprint-in-the-middle-east.

36. Yeşilbursa, Behçet Kemal (22 July 2009)."The Formation of RCD: Regional Cooperation for Development". Middle Eastern Studies. 45 (4): 637-660.

37. Zarar Genghis, China-Pakistan Economy Corridor .. Project that changes international balances: The project carries great strategic importance with an estimated investment of $\$ 64$ billion, Anatolia, Istanbul, 11/28/2018: https://www.aa.com.tr/ar.

38. Zhang Hui, China-Pakistan Economic Corridor: Model for Building a "Belt and Road", China Today, 4/23/2019: http://www.chinatoday.com.cn/ctarabic. 